\title{
УНИФИКАЦИЯ ПРАВОВОГО РЕГУЛИРОВАНИЯ МЕЖДУНАРОДНЫХ РЕЧНЫХ ПЕРЕВОЗОК ГРУЗОВ, ПАССАЖИРОВ И БАГАЖА
}

\begin{abstract}
Аннотация: Настоящая статья посвящена рассмотрению современных унификационных процессов в областимеждународного частного речного права, регулирующего перевозки грузов, пассажиров и багажа в международном речном сообщении. Международное частное речное право является отраслью международного транспортного права, представляюшего собой совокупность норм как национального, так и международного характера, которые регулируют международные транспортные отношения. Международные речные перевозки грузов, пассажиров и багажа осуществляются на основе договоров, заключаемых перевозчиками, содной стороны, игрузоотправителями или пассажсирами, с другой стороны. В статье авторами проведен детальный анализ норм двух основных международных договоров 8 области речных перевозок грузов, пассажиров и багажа, кчислу которых относятся Будапештская конвенция 2001 г. о договоре перевозки грузов по внутренним водным путям (КПГВ) и Женевская конвенция 1976 г. о договоре международной перевозки пассажсиов и багажа по внутренним водным путям (КППВ). Авторы рассматривают международные нормы, регулирующие основное содержание договоров перевозки грузов, пассажиров и багажа, а также ответственность международного речного перевозчика, претензионный порядок урегулирования разногласий, сроки исковой давности и основания обращения к судебному или арбитражному способам разрешения споров.

Review: This article is devoted to the evaluation of the modern unification processes in the sphere of international private river law, regulating transportation of goods, passengers and luggage in the international river transportation communication. The international private river law is a branch of international transportation law, which is a combination of norms of national and international character, regulating international transportation relations. International river transportation of goods, passengers and luggage are made based on contracts between carriers and shippers or passengers. The authors of this article provide detailed analysis of the norms of two key international treaties in the sphere of river transportation: the Budapest Convention of 2001 on the Contract for the Carriage of Goods by Inland Waterway, and the Geneva Convention of 1976 on the Contract for the International Carriage of Passengers and Luggage by Inland Waterway. The authors analyze international norms regarding carriage of goods, passengers and luggage, as well as responsibility of the international river transportation carrier, extrajudicial settlement procedure, limitation periods and grounds for addressing judicial or arbitration conflict resolution means.
\end{abstract}

Ключевые слова: международное транспортное право, международные речные перевозки, международные договоры, национальное законодательство, грузы, пассажиры, багаж, перевозчик, предель ответственности, претензия Keywords: international transportation law, international river transportation, international treaties, national legislation, goods, passengers, luggage, carrier, limits to responsibility, prejudicial claim.

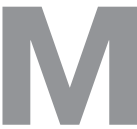
еждународное транспортное право является одной из важнейших отраслей международного частного права и представляет собой совокупность правовых норм, регулирующих международные транспортные отношения, т.е. транспортные отношения, осложненные иностранным элементом. Само международное транспортное право имеет четко выраженную отраслевую структуру, в основе которой лежит использование того или иного вида транспорта, следовательно, мы можем говорить о международном частном морском праве, регулирующем международные морские перевозки грузов, пассажиров и багажа; международном частном воздушном праве, регулирующем международные авиационные перевозки; международном частном автомобильном праве, регулирующем международные автомобильные перевозки, и т.д. Необходимо подчеркнуть, что вышеназванные отрасли международного транспортного права (т.е. подотрасли международного частного права в целом) следует четко отграничивать от смежных с ними по сути и схожих по названию отраслей международного публичного права, таких как международное морское право, международное воздушное право, международное автомобильное право и т.д.

Водораздел между вышеобозначенными нормативными комплексами проходит по предмету правового регулирования. В международном публичном праве предметом регулирования выступают межгосударственные отношения 
DOI: $10.7256 / 1811-9018.2013 .10 .9193$

При цитировании этой статьи сноска на доі обязательна

\section{Право и политика $10(166) \cdot 2013$}

властного характера, имеющие публично-правовую природу, тогда как предметом международного частного права выступают имущественные и личные неимущественные отношения невластного характера, имеющие частноправовую (главным образом, гражданско-правовую) природу. Исходя из этого, можно утверждать, что предметом международного морского права будут межгосударственные отношения властного характера, связанные с использованием морских пространств и установлением их правовых режимов, а предметом международного частного морского права - имущественные отношения невластного характера, связанные с морскими перевозками грузов, пассажиров и багажа. Именно поэтому Монтего-Бейская конвенция ООН по морскому праву от 10 декабря 1982 г. ${ }^{1}$ является источником международного морского права как отрасли международного публичного права, а Гамбургская конвенция ООН о морской перевозке грузов от 31 марта 1978 г. $^{2}$ - источником международного частного морского права.

Аналогичную ситуацию можно наблюдать и применительно к речному праву. Большое сожаление вызывает тот факт, что международное речное право и речные перевозки грузов, пассажиров и багажа в международном сообщении не привлекают пристального внимания ученых в отечественной юридической науке, тем более интересным и актуальным представляется каждое обращение к исследованию указанной тематики. Ряд российских ученых пишет, что международное речное право сложный комплексный массив, носящий исключительно публичный характер ${ }^{3}$, с чем следует безоговорочно согласиться. Вместе с тем другие ученые полагают, что международное речное право - совокупность публичных и частных правовых норм, регулирующих использование и охрану водотоков и водоемов естественного и искусственного происхождения, находящихся на территории двух и более государств ${ }^{4}$. С этой точкой зрения трудно согласиться по следующим причинам.

Наличие частноправовых норм не может служить основанием для отнесения правового комплекса, куда они

\footnotetext{
${ }^{1}$ Бюллетень международных договоров. 1998. № 1. С. 3-168. Данная конвенция вступила в силу 16 ноября 1994 г. После ратификации она вступила в силу для России 11 апреля 1997 г. В настоящее время число государств-участников данной конвенции превышает 160 государств, что придает ей поистине универсальный характер.

2 Закон. 2000. № 6. С. 39-47. Данная конвенция вступила в силу 01 ноября 1992 г. Россия в ней не участвует.

${ }^{3}$ См.: Гуреев С.А., Тарасова И.Н. Международное речное право. M., 1993. С. 3.

${ }^{4}$ См.: Сиваков Д.О. О проблемах развития международного речного права // Законодательство и экономика. 2003. № 12. С. 75.
}

входят, к области частного права, и, наоборот, наличие публично-правовых норм само по себе не свидетельствует о публичном характере того правового комплекса, куда они включаются. Частное право всегда будет содержать нормы публичного характера, а публичное право - нормы частного характера. Речь идет о том, что деление права на публичное и частное определяется предметом регулирования, а не характером входящих в него норм, поэтому международное речное право как отрасль международного публичного права будет регулировать межгосударственные отношения властного характера, связанные с использованием международных речных водотоков и водоемов, путем установления правовых режимов их использования в целях судоходства, рыболовства и ирригации. Именно поэтому к числу источников международного речного права относятся Белградская конвенция о режиме судоходства на Дунае от 18 августа 1948 г.5; Хельсинкская конвенция по охране и использованию трансграничных водотоков и международных озер от 17 марта 1992 г., Европейское соглашение о важнейших внутренних водных путях международного значения (СМВП) от 19 января 1996 г. ${ }^{7}$

Международное частное речное право как отрасль международного транспортного права и подотрасль международного частного права регулирует частноправовые отношения невластного характера, связанные с международными речными перевозками грузов, пассажиров и багажа, т.е. с такими перевозками, которые осуществляются по внутренним водным путям, пролегающим на территории нескольких государств. В этих случаях речь идет о международных речных и озерных системах (например, Дунайском, Рейнском, Амурском водных бассейнах и т.д.). Целесообразность унификации правил перевозок грузов по внутренним водным путям международного значения привела к принятию Будапештской конвенции о договоре перевозки грузов по внутренним водным путям (КПГВ) от 22 июня 2001 г. $^{8}$ (далее - Будапештская конвенция). Целесообразность унификации правил перевозок

\footnotetext{
5 Действующее международное право. М., 1996. Т. 1. С. 211-222. Данная конвенция вступила в силу 11 мая 1949 г. После ратификации она вступила в силу для СССР 11 мая 1949 г.

${ }^{6}$ Бюллетень международных договоров. 1999. № 10. С. 3-18. Данная конвенция вступила в силу 06 октября 1996 г. После принятия она вступила в силу для России 06 октября 1996 г.

${ }^{7}$ Бюллетень международных договоров. 2002. № 12. С. 12-36. Дане соглашение вступило в силу 26 июля 1999 г. После утверждения оно вступило в силу для России 29 августа 2002 г.

${ }^{8}$ СЗ РФ. 2007. № 44. Ст. 5284. Будапештская конвенция вступила в силу 01 апреля 2005 г. После присоединения она вступила в силу для России 01 августа 2007 г.
} 
DOI: $10.7256 / 1811-9018.2013 .10 .9193$

При цитировании этой статьи сноска на доі обязательна

Международное право в XXI веке

пассажиров и багажа по внутренним водным путям международного значения привела к принятию Женевской конвенции о договоре международной перевозки пассажиров и багажа по внутренним водным путям (КППВ) от 01 мая 1976 г. ${ }^{9}$ (далее - Женевская конвенция).

Структурно и Будапештская, и Женевская конвенции соответствуют общей схеме построения транспортных конвенций, регулирующих перевозки грузов, пассажиров и багажа каким-либо видом транспорта (с этой целью можно упомянуть Женевскую конвенцию ЕЭК ООН о договоре международной дорожной перевозки грузов (КДПГ) от 10 мая 1956 г. ${ }^{10}$, а также Афинскую конвенцию ИМО о перевозке морем пассажиров и их багажа от 13 декабря 1974 г. $\left.^{11}\right)$. Вместе с тем неоспоримая важность обеих конвенций для целей развития международного частного речного права подвигает нас к их детальному рассмотрению и анализу ${ }^{12}$.

\section{1) Правовое регулирование международных речных перевозок грузов}

\section{а) Основные понятия и область применения Бу- дапештской конвенции}

По смыслу Будапештской конвенции основные понятия международного частного речного права имеют следующее значение:

- «договор перевозки» означает любой договор независимо от его квалификации, в соответствии с которым перевозчик за уплату фрахта обязуется перевезти груз по внутренним водным путям;

- «перевозчик» означает любое лицо, которым или от имени которого с грузоотправителем был заключен договор перевозки;

\footnotetext{
9 Документ опубликован не был. В настоящее время Женевская конвенция в силу не вступила. СССР присоединился к ней 19 февраля 1981 г.

${ }^{10}$ Международные перевозки грузов. СПб., 1993. С. 21-40. КДПГ вступила в силу 02 июля 1961 г. После присоединения конвенция вступила в силу для СССР 30 ноября 1983 г. Россия является участницей КДПГ в порядке международного правопреемства.

${ }^{11}$ ВВС СССР. 1983. № 38. Ст. 570. Данная конвенция вступила в силу 28 апреля 1987 г. После присоединения для СССР она вступила в силу 28 апреля 1987 г. Россия является ее участницей в порядке международного правопреемства.

${ }^{12}$ Согласно российскому праву договор перевозки грузов, пассажиров и багажа имеет двусторонний, возмездный, реальный либо консенсуальный характер; ответственность перевозчика за неисполнение или ненадлежащее исполнение своих обязательств носит ограниченный характер; предусмотрен претензионный порядок урегулирования споров и сокращенные сроки исковой давности.
}

- «фактический перевозчик» означает любое лицо, иное, чем служащий или агент перевозчика, которому перевозчиком поручено осуществление перевозки или части этой перевозки;

- «грузоотправитель» означает любое лицо, которым или от имени которого был заключен договор перевозки с перевозчиком;

- «грузополучатель» означает лицо, управомоченное на получение груза;

- «транспортный документ» означает документ, подтверждающий договор перевозки груза и прием или погрузку груза на судно перевозчиком, составленный в виде коносамента или накладной либо в виде любого другого используемого в коммерческой практике документа.

Термин «груз» не охватывает буксируемые или толкаемые суда и не включает багаж и транспортные средства пассажиров. Если товары объединены в контейнере на поддоне или на подобном приспособлении для транспортировки, термин «груз» включает такое приспособление для транспортировки, если оно предоставлено грузоотправителем. Выражение «письменная форма» охватывает, если только заинтересованные лица не договорились об ином, положение, при котором информация передается с помощью электронного, оптического или любого другого аналогичного средства связи, включая телеграф, телефакс, телекс, электронную почту или электронный обмен данными (ЭОД), но не ограничиваясь ими, при условии, что эта информация доступна для последующего использования в качестве исходной информации (ст. 1).

Будапештская конвенция применяется к любому договору перевозки, в соответствии с которым порт погрузки (или место приема груза) и порт разгрузки (или порт сдачи груза) расположены в двух различных государствах, из которых по крайней мере одно является государством-участником данной конвенции. Если договор предусматривает возможность выбора между несколькими портами разгрузки или местами сдачи, то таким портом или местом сдачи является порт разгрузки или сдачи, в котором фактически был сдан груз. Если предметом договора перевозки по внутренним водным путям является перевозка груза без перевалки как по внутренним водным путям, так и по путям, на которые распространяется режим морской перевозки, Будапештская конвенция применяется и к этому договору при соблюдении вышеуказанных условий, за исключением тех случаев, когда в соответствии с применимым морским законодательством был составлен морской коносамент или когда расстояние, которое предстоит пройти по путям, под- 
DOI: $10.7256 / 1811-9018.2013 .10 .9193$

При цитировании этой статьи сноска на dоі обязательна

\section{Право и политика $10(166) \cdot 2013$}

падающим под режим морской перевозки, является более длинным. Будапештская конвенция применяется независимо от национальной принадлежности, места регистрации, порта приписки судна, квалификации судна как судна морского плавания или внутреннего плавания и независимо от национальной принадлежности, места жительства, места нахождения или места пребывания перевозчика, грузоотправителя или грузополучателя (ст. 2).

б) Права и обязанности сторон договора перевозки груза по внутренним водным путям международного значения

Перевозчик обязан перевези груз в надлежащие сроки и сдать его в месте сдачи грузополучателю в том же состоянии, в каком груз им был получен при погрузке ${ }^{13}$. В случае отсутствия договоренности об ином, прием груза и его сдача производятся на борту судна. Перевозчик определяет, какое судно он будет использовать. Он обязан до и в начале рейса проявить должную заботливость, с тем чтобы судно было в состоянии принять груз, было пригодным для плавания, оснащено и укомплектовано экипажем, и чтобы на нем имелись национальные и международные разрешения, необходимые для перевозки соответствующего груза. Если оговорено, что перевозка должна осуществляться на определенном судне или на определенном типе судна, перевозчик может переместить груз полностью или частично на другое судно или другой тип судна без согласия грузоотправителя только в следующих случаях:

- $\quad$ при наступлении таких обстоятельств, как низкий уровень воды, столкновение либо иные препятствия, влияющие на судоходство, которые невозможно было предвидеть в момент заключения договора и перевозчик не может получить в течение разумного периода времени указания от грузоотправителя;

- $\quad$ когда это соответствует обычаям порта, в котором находится судно.

\footnotetext{
${ }^{13} \mathrm{~B}$ соответствии со ст. 785 второй части ГК РФ по договору перевозки груза перевозчик обязуется доставить вверенный ему отправителем груз в пункт назначения и выдать его получателю, а отправитель обязуется уплатить за перевозку груза установленную плату. Заключение договора перевозки груза подтверждается составлением и выдачей отправителю груза транспортной накладной - коносамента или иного документа. В.В. Витрянский справедливо полагает, что договор перевозки груза может быть квалифицирован как реальный, поскольку обязательства перевозчика возникают лишь в отношении такого груза, который сдан грузоотправителем и принят перевозчиком для его доставки в пункт назначения (вверенный перевозчику груз). (См.: Витрянский В.В. Понятие и виды договора перевозки. Система договоров перевозки // Хозяйство и право. 2001. № 1. С. 61).
}

Перевозчик имеет право перевозить грузы на палубе или в открытых трюмах только в том случае, если это было оговорено с грузоотправителем или соответствует обычаям данной отрасли торговли либо требуется действующими предписаниями (ст. 3).

Договор, заключенный между перевозчиком и фактическим перевозчиком, является договором перевозки по смыслу Будапештской конвенции. Для целей такого договора все положения конвенции, относящиеся к грузоотправителю, применяются к перевозчику, а положения, относящиеся к перевозчику, применяются к фактическому перевозчику. В тех случаях, когда перевозчик поручил осуществление перевозки или ее части фактическому перевозчику, даже если это допустимо условиями договора перевозки, перевозчик остается ответственным за всю перевозку. Все положения Будапештской конвенции, регулирующие ответственность перевозчика, применяются к ответственности фактического перевозчика в отношении осуществляемой им перевозки.

Перевозчик во всех случаях информирует грузоотправителя об осуществлении перевозки или ее части фактическим перевозчиком. Любое соглашение с грузоотправителем или грузополучателем, расширяющее ответственность перевозчика, распространяется на фактического перевозчика только в том объеме, на который он дал явно выраженное согласие в письменной форме. Фактический перевозчик может ссылаться на любые возражения, которые могут быть выдвинуты перевозчиком на основе договора перевозки. В тех случаях, когда перевозчик и фактический перевозчик несут ответственность, их ответственность является солидарной, что нисколько не умаляет права регрессного требования в отношениях между ними (ст. 4).

Грузоотправитель должен оплатить суммы, причитающиеся в силу договора перевозки. Грузоотправитель обязан до передачи груза перевозчику представить ему в письменной форме следующие данные о грузе, подлежащем перевозке:

- сведения о размере, количестве мест, весе и погрузочном объеме груза;

- $\quad$ сведения о маркировке, необходимой для идентификации груза;

- сведения о характере, особенностях и свойствах груза;

- сведения о таможенном или административном режиме, применимом к грузу;

- $\quad$ другие необходимые сведения, которые указываются в транспортном документе.

Кроме того, грузоотправитель должен передать перевозчику во время сдачи груза все необходимые сопроводи- 
DOI: $10.7256 / 1811-9018.2013 .10 .9193$

При цитировании этой статьи сноска на dоі обязательна

Международное право в XXI веке

тельные документы. Грузоотправитель должен упаковать груз таким образом, чтобы предупредить его утерю или повреждение с момента его принятия перевозчиком к перевозке и до выдачи грузополучателю, а также исключить возможность причинения им ущерба судну или другому грузу. Грузоотправитель должен произвести надлежащую маркировку груза в соответствии с применимыми международными или национальными предписаниями либо в соответствии с общепринятыми во внутреннем судоходстве правилами и обычаями. При условии соблюдения перевозчиком своих обязательств грузоотправитель должен погрузить, уложить и закрепить груз в соответствии с практикой судоходства на внутренних водных путях, если в договоре перевозки не указано иное (ст. 6).

Грузоотправитель, даже если никакая ошибка не может быть вменена ему в вину, несет ответственность за убытки и издержки, понесенные перевозчиком или фактическим перевозчиком в силу того факта, что:

1) сведения или информация, сообщенные им перевозчику, отсутствуют, являются неточными или неполными;

2) опасный или загрязняющий окружающую среду груз не был надлежащим образом маркирован или обозначен в соответствии с применимыми международными или национальными предписаниями либо в соответствии с общепринятыми во внутреннем судоходстве правилами и обычаями;

3) необходимые сопроводительные документы отсутствуют, являются неточными или неполными.

Перевозчик не может ссылаться на ответственность грузоотправителя, если установлено, что это вина самого перевозчика, его агентов или служащих. Данное правило применяется и к фактическому перевозчику (ст. 8).

Перевозчик выдает для каждой перевозки груза транспортный документ; он должен выдать коносамент только по просьбе грузоотправителя и если это было оговорено до погрузки груза или до его принятия к перевозке ${ }^{14}$. Отсутствие транспортного документа или его неполное оформление не влияет на действительность договора перевозки. Оригинал транспортного документа подписывается перевозчиком или капитаном судна либо лицом, уполномоченным перевозчиком. Перевозчик может потребовать,

\footnotetext{
${ }^{14}$ Оригиналы коносамента представляют собой ценные бумаги ордерные или на предъявителя. В месте выдачи груз выдается только против передачи первого из предъявленных оригиналов коносамента, впоследствии выдача груза не может быть потребована против передачи других оригиналов. Когда груз находится в распоряжении перевозчика, передача коносамента лицу, управомоченному согласно коносаменту получить груз, влечет те же последствия, что и передача груза в том, что касается прав на получение груза (ст. 13).
}

чтобы грузоотправитель скрепил подписью оригинал или копию документа. Подпись может быть проставлена от руки, в виде факсимильной печати, пробита или проштемпелевана, проставлена в виде символов или нанесена при помощи любого другого механического или электронного средства, если это не запрещается законодательством государства, где выдается транспортный документ.

Транспортный документ удостоверяет, при отсутствии доказательств противного, заключение и содержание договора перевозки, а также принятие груза к перевозке перевозчиком. В частности, он является основой для презумпции, что груз принят к перевозке в состоянии, описанном в транспортном документе. В том случае, когда транспортным документом является коносамент, он определяет отношения между перевозчиком и грузополучателем. Условия договора перевозки попрежнему определяют отношения между перевозчиком и грузоотправителем. Транспортный документ, помимо своего наименования, содержит следующие данные:

- $\quad$ наименование, место жительства, место нахождения или место пребывания перевозчика и грузоотправителя;

- наименование грузополучателя;

- $\quad$ название или номер судна, если груз погружен на борт, либо указание в транспортном документе, что груз был принят перевозчиком, но еще не погружен на борт судна;

- $\quad$ порт погрузки (или место приема груза) и порт выгрузки (либо место сдачи груза);

- $\quad$ наименование типа груза и характер его упаковки, а в случае опасного или загрязняющего окружающую среду груза его обозначение в соответствии с действующими предписаниями или его общее наименование;

- $\quad$ размеры, количество мест или вес, а также идентификационную маркировку груза, принятого на борт или принятого к перевозке;

- $\quad$ указание о том, что груз должен или может перевозиться на палубе или в открытых трюмах;

- $\quad$ согласованные положения, касающиеся фрахта;

- $\quad$ в случае накладной - точное указание того, является ли она оригиналом или копией; в случае коносамента - количество экземпляров оригинала;

- $\quad$ место и дата выдачи.

Отсутствие одного или нескольких вышеуказанных реквизитов не влияет на юридический характер транспортного документа (ст. 11). Перевозчик вправе вносить в транспортный документ оговорки относительно идентификационной маркировки и внешнего состояния груза. Если перевозчик не указывает внешнее состо- 
DOI: 10.7256/1811-9018.2013.10.9193

При цитировании этой статьи сноска на доі обязательна

\section{Право и политика 10 (166) • 2013}

яние груза или не вносит оговорок по этому поводу, считается, что он обозначил в транспортном документе внешнее состояние груза как хорошее (ст. 12).

Грузоотправитель имеет право распоряжаться гру3ом; в частности, он может потребовать, чтобы перевозчик прекратил перевозку груза, чтобы он изменил место сдачи или сдал груз не тому получателю, который указан в транспортном документе. Грузоотправитель теряет предоставленное ему право распоряжаться грузом с того момента, когда грузополучатель после прибытия груза в предусмотренное место доставки потребовал сдать груз. В случае перевозки груза по накладной таким моментом выступает момент передачи грузополучателю оригинала накладной; в случае перевозки по коносаменту - момент передачи грузоотправителем всех имеющихся у него оригиналов коносамента другому лицу. Посредством соответствующего указания в накладной грузоотправитель может в момент выдачи последней отказаться от своего права распоряжения в пользу грузополучателя. Грузоотправитель или грузополучатель для осуществления своего права распоряжения должен:

1) в случае, когда был выдан коносамент, представить все оригиналы коносамента до прибытия груза в предусмотренное место сдачи;

2) в случае, когда был выдан иной транспортный документ, кроме коносамента, представить этот документ, который должен содержать новые указания для перевозчика;

3) в случае, когда перевозчику были даны новые указания, возместить перевозчику все расходы и убытки, понесенные в связи с выполнением указаний;

4) в случае выгрузки груза до прибытия в предусмотренное место сдачи оплатить полную сумму фрахта, если в договоре перевозки не было оговорено иное (ст. 14-15).

в) Ответственность перевозчика за ущерб, причиненный в результате утраты или повреждения груза

Перевозчик несет ответственность за ущерб, причиненный в результате утраты или повреждения груза, происшедших после его принятия к перевозке до его сдачи, либо в результате превышения срока сдачи, если он не докажет, что ущерб обусловлен обстоятельствами, которых заботливый перевозчик не мог избежать и последствия которых он не мог предотвратить. Ответственность перевозчика за ущерб, причиненный в результате утраты или повреждения груза в течение времени до погрузки груза на судно или после того, когда груз был выгружен с судна, определяется в соответствии с законодательством государства, применимым к договору перевозки. Перевозчик отвечает за действия и бездействие своих служащих и агентов, которых он использует во время выполнения договора перевозки, в той же степени, что и за свои собственные действия и бездействие, если эти лица действуют в пределах своих служебных обязанностей. В том случае, когда перевозка осуществляется фактическим перевозчиком, перевозчик также отвечает за действия и бездействие фактического перевозчика, его служащих и агентов, действующих в пределах своих служебных обязанностей (ст. 16-17).

Перевозчик и фактический перевозчик освобождаются от ответственности, если утрата, повреждение или задержка в доставке груза являются результатом одного из перечисленных ниже обстоятельств или рисков:

- действия или бездействие грузоотправителя, грузополучателя или лица, уполномоченного распоряжаться грузом;

- $\quad$ перемещения, погрузки или выгрузки груза грузоотправителем или грузополучателем либо третьими лицами, действующими по поручению грузоотправителя или грузополучателя;

- перевозки груза на палубе или в открытых трюмах, если это было оговорено с грузоотправителем или соответствует обычаям данной отрасли торговли либо требуется действующими предписаниями;

- $\quad$ характера определенных видов груза, с которым связаны полная или частичная утрата или повреждение, в частности от поломки, ржавчины, внутренней порчи, усушки, утечки, естественной убыли при транспортировке (по объему или по весу) или от воздействия паразитов либо грызунов;

- $\quad$ отсутствия или дефектов упаковки, когда груз в силу своего характера подвержен потере или повреждению при отсутствии упаковки или наличия в ней дефектов;

- недостаточной или неточной идентификационной маркировки груза;

- проведения операций или попытки проведения операций по спасанию жизни или имущества на внутренних водных путях;

- перевозки живых животных кроме тех случаев, когда перевозчиком не были приняты соответствующие меры или не были соблюдены инструкции, согласованные в договоре перевозки (ст. 18).

В том случае, когда перевозчик несет ответственность за полную утрату груза, причитающаяся с него сумма возмещения равняется стоимости груза в месте и в день его сдачи в соответствии с договором перевозки. Сдача груза неуправомоченному лицу рассматривается как его утрата. В случае частичной утраты или повреждения груза 
DOI: $10.7256 / 1811-9018.2013 .10 .9193$

При цитировании этой статьи сноска на dоі обязательна

Международное право в XXI веке

перевозчик несет ответственность лишь в той степени, в которой стоимость груза понизилась. Стоимость груза определяется в соответствии с его стоимостью на бирже; при отсутствии последней - в зависимости от рыночной цены; за отсутствием и того, и другого - согласно обычной стоимости груза того же характера и качества в месте сдачи. В случае, если груз в силу своего характера подвержен убыли при транспортировке, то перевозчик независимо от продолжительности перевозки несет ответственность только за ту долю убыли, которая превышает естественную убыль (по объему или весу), оговоренную сторонами договора перевозки, либо при отсутствии такой договоренности предписанную правилами и практикой, действующими в месте назначения. Выплата перевозчиком возмещения не затрагивает право перевозчика на получение фрахта, предусмотренного договором перевозки либо применимыми национальными правилами или практикой (ст. 19).

Перевозчик несет ответственность в сумме, не превышающей 666,67 расчетных единиц на каждое грузовое место или другую единицу отгрузки либо 2 расчетные единицы за каждый килограмм указанного в транспортном документе веса утраченного или поврежденного груза в зависимости от того, какая сумма больше ${ }^{15}$. Если грузовым местом или иной единицей отгрузки является контейнер и если в транспортном документе не указано количество грузовых мест или единиц отгрузки как упакованных в контейнере, сумма 666,67 расчетных единиц заменяется на сумму 1500 расчетных единиц за контейнер, не содержащий груза, и дополнительно сумму 25000 расчетных единиц за грузы, которые были помещены в контейнер. Когда для объединения груза используется контейнер, поддон или подобное приспособление для транспортировки, в качестве грузового места или другой единицы отгрузки рассматривается любое грузовое место или единица отгрузки, указанные в транспортном документе как находящиеся на этом приспособлении для транспортировки. За указанным исключением груз, находящийся на этом приспособлении для транспортировки, рассматривается в качестве одной единицы отгрузки.

В тех случаях, когда утрачено или повреждено само приспособление для транспортировки, это приспособле-

\footnotetext{
15 Под расчетной единицей Будапештская конвенция понимает расчетную единицу, действующую в рамках Международного валютного фонда - специальные права заимствования (СДР). Суммы, указанные в СДР, переводятся в национальную валюту какого-либо государства в соответствии с котировкой данной валюты по отношению к СДР на дату судебного решения или на дату, оговоренную сторонами договора перевозки (ст. 28). Таким образом, реальные расчеты осуществляются в национальной валюте какого-либо государства.
}

ние, если оно не является собственностью перевозчика и не предоставлено им, рассматривается в качестве отдельной единицы отгрузки. В случае ущерба, вызванного задержкой сдачи груза, перевозчик несет ответственность лишь в размере, не превышающем величину фрахта. Однако общая сумма возмещения не может превышать предельную величину, которая применяется в случае полной утраты груза, в отношении которого возникла такая ответственность. Максимальные пределы ответственности не применяются:

1) если характер и более высокая стоимость такого груза или приспособления для транспортировки были прямо указаны в транспортном документе и перевозчик не оспорил эти данные;

2) если стороны четко оговорили более высокие максимальные пределы ответственности.

Общая сумма, которая может быть взыскана с перевозчика, фактического перевозчика и их служащих и агентов за нанесение одного и того же ущерба, не должна в совокупности превышать пределы ответственности, предусмотренные выше (ст. 20). Перевозчик или фактический перевозчик не может ссылаться на освобождение от ответственности и ее пределы, предусмотренные в Конвенции или в договоре перевозки, если доказано, что ущерб причинен в результате его собственного действия или собственного бездействия, совершенных умышленно или по грубой неосторожности. Равным образом служащие и агенты, действующие по поручению перевозчика или фактического перевозчика, не могут ссылаться на освобождение от ответственности и ее пределы, предусмотренные в Будапештской конвенции или в договоре перевозки, если доказано, что они причинили ущерб в результате их собственных действий или собственного бездействия, совершенных умышленно или по грубой неосторожности (ст. 21). Предусмотренные в Будапештской конвенции или в договоре перевозки основания освобождения от ответственности и ее пределы применимы при любом иске по поводу утраты, повреждения или задержки сдачи груза, на который распространяется договор перевозки независимо от того, основан ли этот иск на деликтной или договорной ответственности либо на ином правовом основании (ст. 22).

2) Порядок разрешения споров, связанных с неисполнением или ненадлежащим исполнением договора перевозки грузов по внутренним водным путям международного значения

Безоговорочное принятие груза грузополучателем является, если не установлено иное, доказательством сдачи 
DOI: 10.7256/1811-9018.2013.10.9193

При цитировании этой статьи сноска на dоі обязательна

\section{Право и политика 10 (166) • 2013}

перевозчиком груза в том состоянии и в том количестве, в котором он ему был передан для перевозки. Перевозчик и грузополучатель могут потребовать проведения проверки состояния и количества груза в момент его сдачи в присутствии обеих сторон. Если утрата или повреждение груза являются очевидными, то любая оговорка грузополучателя должна быть заявлена в письменной форме с указанием общего характера повреждения не позднее момента сдачи груза, если она не была сделана ранее при проведении совместного осмотра сторонами. Если утрата или повреждение груза не являются очевидными, то любая оговорка грузополучателя должна быть заявлена в письменной форме с указанием общего характераповреждения непозднее чем через 7 календарных дней с момента сдачи, причем потерпевшая сторона в этом случае должна доказать, что повреждение было нанесено в то время, когдаэтотгруз находился в распоряжении перевозчика. Никакая компенсация не полагается за ущерб, вызванный задержкой сдачи груза, если грузополучатель не докажет, что перевозчику было сделано уведомление о задержке в течение 21 календарного дня с момента сдачи груза и что это уведомление дошло до перевозчика (ст. 23).

Право на иск, связанный с договором, положения которого регулируются Будапештской конвенцией, погашается по истечении одного года, начиная с того дня, когда груз был сдан или должен был быть сдан грузополучателю. День, с которого начинает исчисляться исковая давность, в этот срок не включается. Лицо, которому был предъявлен иск, может в любой момент в течение срока исковой давности продлить этот срок путем соответствующего заявления, сделанного в письменной форме потерпевшему. Данный срок может быть вновь продлен посредством одного или нескольких других заявлений. Приостановление и перерыв течения срока исковой давности регулируются законодательством государства, которое применяется к договору перевозки. Предъявление требования во время процедуры разбирательства с целью применения права на ограничение ответственности в отношении всех требований, вытекающих из события, которое повлекло за собой ущерб, прерывает исковую давность.

Иск о возмещении убытков может быть предъявлен любым лицом, признанным ответственным в силу Будапештской конвенции, даже по истечении срока исковой давности, если этот процесс начинается в течение 90 дней, считая со дня, когда лицо, предъявляющее требование, его урегулировало или когда ему в установленном порядке была вручена повестка о возбуждении против него разбирательства, либо в пределах более продолжительного срока, предусмотренного законодательством государства, в котором проводится разбирательство. Право на иск, погашенное за давностью, не может быть использовано в форме встречного иска или зачета требования (ст. 24).

Любое положение договора, предусматривающее исключение, ограничение или усиление по смыслу Будапештской конвенции ответственности перевозчика, фактического перевозчика или их служащих и агентов, перенесение бремени доказывания или сокращение срока предъявления претензии, признается недействительным. Признается также недействительной оговорка, предусматривающая передачу в пользу перевозчика прав страхования груза. Правомерными положениями договора являются те, которые предусматривают, что перевозчик или фактический перевозчик не несет ответственности за ущерб, причиненный:

- действием или бездействием капитана, лоцмана или любого другого лица, обслуживающего судно, толкач или буксир, совершенным в ходе плавания или во время формирования либо расформирования толкаемого или буксируемого состава при условии, что перевозчик выполнил обязательство в отношении укомплектования экипажа, если только это действие или бездействие не были совершены с намерением нанести ущерб либо по грубой неосторожности;

- $\quad$ пожаром или взрывом на борту судна, если нельзя доказать, что пожар или взрыв являются результатом ошибки собственно перевозчика или фактического перевозчика, их служащих и агентов либо дефектов судна;

- $\quad$ в результате имевшихся до начала рейса дефектов судна перевозчика или фактического перевозчика либо зафрахтованного ими судна, если они докажут, что эти дефекты не могли быть обнаружены до начала рейса, несмотря на проявленную должную заботливость (ст. 25).

При отсутствии надлежащих положений в Будапештской конвенции договор перевозки регулируется законодательством государства, выбранным по соглашению сторон. При отсутствии соглашения применяется законодательство государства, с которым договор перевозки наиболее тесно связан. Предполагается, что договор перевозки наиболее тесно связан с государством, в котором находилось основное предприятие перевозчика в момент заключения договора, если в этом государстве находится также порт погрузки (или место приема груза) или порт разгрузки (или место сдачи) либо основное предприятие перевозчика. Если у перевозчика нет предприятия на суше и он заключает договор перевозки на борту судна, предполагается, что договор 
наиболее тесно связан с государством, в котором это судно зарегистрировано или под флагом которого оно плавает, если в этом государстве находится также порт погрузки (или место приема груза) или порт разгрузки (или место сдачи) либо основное предприятие грузоотправителя (ст. 29) ${ }^{16}$.

\section{2) Правовое регулирование международных речных перевозок пассажиров и багажа}

\section{а) Основные понятия и область применения Женевской конвенции}

Женевская конвенция применяется ко всякому договору перевозки пассажиров и, в соответствующих случаях, их багажа по внутренним водным путям, когда в договоре предусмотрено, что перевозка производится по водным путям не менее двух государств и что место посадки или место высадки, или и то, и другое, находятся на территории одного из Договаривающихся государств. Женевская конвенция применяется и в том случае, если используемое судно не является судном внутреннего плавания, а также независимо от национального флага, страны регистрации судна и местожительства или гражданства заключающих договор сторон. Женевская конвенция не применяется, если на договор перевозки распространяются:

- $\quad$ положения морского права в силу того, что перевозка осуществляется частично по морю;

- положения железнодорожного права в силу какой-либо международной конвенции.

При применении Женевской конвенции:

1) «перевозчик» означает либо лицо, которое в качестве профессионального перевозчика обязуется во исполнение индивидуального или коллективного договора перевозки перевезти одно или несколько лиц и, в соответствующих случаях, их багаж, независимо от того, само ли оно выполняет эту перевозку или нет;

2) «пассажир» означает любое лицо, которое во исполнение договора перевозки, заключенного им самим или от его имени, перевозится за плату или бесплатно перевозчиком;

\footnotetext{
${ }^{16}$ Следует отметить, что Будапештская конвенция не регулирует вопросы выбора юрисдикционного органа по разрешению спора, вытекающего из договора перевозки, ничего не говоря ни о пророгационном соглашении, ни об арбитражном соглашении. Это значит, что данный вопрос разрешается по усмотрению спорящих сторон с учетом положений соответствующего национального процессуального законодательства и применимых международных договоров.
}

3) «багаж» означает любой предмет, перевозимый в соответствии с договором перевозки, включая транспортные средства, но исключая автобусы и грузовые автомобили, используемые для коммерческих перевозок.

Женевская конвенция применяется и в том случае, если договор перевозки заключен государством или юридическим лицом публичного права (п. 1-4 ст. 1). При применении Женевской конвенции перевозчик отвечает в такой же мере, как за свои собственные действия и упущения, за действия и упущения своих агентов и любых других лиц, к услугам которых он прибегает для выполнения обязательств, возлагаемых на него в силу договора перевозки, когда эти агенты или эти лица, действуют в переделах своих обязанностей (ст. 2).

б) Основные транспортные документы, применяемые в международных речных перевозках пассажсиров и багажа

При перевозке пассажиров перевозчик должен выдать индивидуальный или коллективный билет ${ }^{17}$. Отсутствие, неправильность оформления или потеря билета не затрагивают существования или действительности договора перевозки, который продолжает подпадать под действие положений Женевской конвенции. В билете должен быть обозначен перевозчик и указано, что договор подпадает под действие положений Женевской конвенции даже при наличии каких-либо противоречащих этому оговорок, путем включения указания «применяется КППВ». Перевозчик несет ответственность за вред, который может быть причинен пассажиру в результате нарушения им обязательств, возлагаемых на него в соответствии с настоящей статьей. Билет, если не доказано обратное, служит подтверждением содержащихся в нем условий. Если в билете не указано обратное, то его можно, когда он не является именным, передавать другому лицу до начала перевозки (ст. 3).

\footnotetext{
${ }^{17}$ В соответствии со ст. 786 второй части ГК РФ по договору перевозки пассажира перевозчик обязуется перевезти пассажира в пункт назначения, а в случае сдачи пассажиром багажа также доставить багаж в пункт назначения и выдать его управомоченному на получение багажа лицу; пассажир обязуется уплатить установленную плату за проезд, а при сдаче багажа - и за провоз багажа. Заключение договора перевозки пассажира удостоверяется билетом, а сдача пассажиром багажа - багажной квитанцией. Договор перевозки пассажира, по мнению В.В. Витрянского, двусторонний, возмездный. Не вызывает сомнений также его консенсуальный характер: обязанность перевозчика подать подвижной состав и предоставить пассажиру место в соответствующем транспортном средстве, а также принять от него багаж возникает с момента приобретения пассажиром провозного билета (См.: Витрянский В.В. Указ. соч. С. 61).
} 
DOI: $10.7256 / 1811-9018.2013 .10 .9193$

При цитировании этой статьи сноска на dоі обязательна

\section{Право и политика 10 (166) • 2013}

Если пассажир желает сдать багаж перевозчику и последний принимает этот багаж, то перевозчик может выдать, в соответствующих случаях в сочетании с билетом, багажную квитанцию или другой аналогичный документ, в котором указываются количество и характер сдаваемого ему багажа; при наличии просьбы пассажира выдача этой багажной квитанции является обязательной. В случае выдачи багажной квитанции считается, что действующий добросовестно перевозчик произвел действительную выдачу багажа, если он выдал багаж предъявителю багажной квитанции. Если квитанция не предъявляется, то перевозчик обязан выдать багаж, на который была выдана квитанция, только при условии, если лицо, претендующее на выдачу этого багажа, докажет свое право на его получение; если это доказательство представляется недостаточным, перевозчик может потребовать внесения соответствующего залога, который возвращается по истечении одного года, считая со дня его внесения. Багаж, не востребованный по прибытии судна, независимо от того, выдана ли на него багажная квитанция или нет, сдается на хранение в соответствующее надежное место. Перевозчик хранит его за счет пассажира; он может поручить хранение третьему лицу. Хранитель багажа имеет право на справедливое вознаграждение. Хранение багажа регулируется законодательством, действующим в месте сдачи багажа на хранение (ст. 4).

\section{в) Ответственность перевозчика за ущерб, причиненный пассажсру и багажу}

Перевозчик несет ответственность за ущерб, связанный со смертью, телесными повреждениями или нанесением любого другого вреда физическому или психическому здоровью пассажира, если происшествие, повлекшее за собой этот ущерб, связано с перевозкой и имело место либо во время нахождения пассажира на судне, либо во время его посадки или высадки, либо в связи с погрузкой или выгрузкой и выдачей багажа, и обусловлено виной перевозчика или лиц, за которых он несет ответственность ${ }^{18}$. Эта вина презюмируется, если не доказано обратное в тех случаях, когда смерть, телесные повреждения или нанесение любого другого вреда физическому или психическому здоровью пассажира

\footnotetext{
${ }^{18}$ Национальное законодательство, которое сочтет применимым рассматривающий дело суд, определяет размер ущерба, причиненного в связи со смертью, телесными повреждениями или нанесением любого другого вреда физическому или психическому здоровью пассажира, и лиц, имеющих право на возмещение ущерба (ст. 6).
}

вызваны кораблекрушением, столкновением, посадкой на мель, взрывом или пожаром или связаны с одним из этих событий. Перевозчик несет ответственность за вышеуказанный ущерб, если этот ущерб причинен:

- $\quad$ в результате неисправности судна или бортовой аппаратуры, или

- по вине лица, у которого перевозчик нанял судно, или лиц, за которых такое лицо несло бы ответственность, если бы оно само являлось перевозчиком (ст. 5).

Общая сумма возмещения, которая должна быть выплачена перевозчиком в связи с одним и тем же событием, не может превышать 200000 золотых франков на одного пострадавшего ${ }^{19}$. Эта сумма не включает понесенные сторонами для доказательства своих прав судебные издержки или другие расходы, уплата или возмещение которых могут быть возложены на перевозчика, а также проценты, исчисляемые в соответствии с законом, который сочтет применимым рассматривающий дело суд. Стороны договора перевозки могут договориться об установлении более высокого предела возмещения. Если не установлено иное, то такая договоренность распространяется на всех лиц, имеющих право на возмещение. Ограничения размеров возмещения, установленные в силу настоящей статьи, применяются ко всем требованиям, связанным со смертью, телесными повреждениями или нанесением любого другого вреда физическому или психическому здоровью пассажира. Если имеется несколько истцов и если общая сумма их требований превышает установленный максимум, то выплаты пропорционально сокращаются (ст. 7).

Перевозчик несет ответственность за ущерб, связанный с полной или частичной утратой багажа и с его повреждениями, если происшествие, вызвавшее такой ущерб, имело место во время перевозки и обусловлено виной перевозчика или лиц, за которых он несет ответственность. Эта вина презюмируется, если не доказано обратное:

1) если утрата или повреждение багажа были вызваны кораблекрушением, столкновением, посадкой на мель, взрывом или пожаром или связаны с одним из этих событий;

\footnotetext{
19 Золотой франк - специальная расчетная единица, эквивалентная стоимости 10/31 г золота 900-й пробы, которая используется в ряде международных транспортных конвенций, например, в КДПГ. Суммы в золотых франках переводятся в национальную валюту государства, в суде которого рассматривается дело, в соответствии с официальным курсом этой валюты по отношению к золотому франку, или в том случае, если официальный курс не установлен, в соответствии с курсом, установленным компетентным органом заинтересованного государства (п. 2 ст. 14).
} 
DOI: $10.7256 / 1811-9018.2013 .10 .9193$

При цитировании этой статьи сноска на dоі обязательна

Международное право в XXI веке

2) если багаж был сдан перевозчику в период между моментом, когда последний принял багаж, и моментом, когда багаж был либо получен лицом, имеющим право на его получение, либо сдан на хранение, предусмотренное в ст. 4. Данное правило не применяется ни к транспортным средствам, перевозимым на борту судна, ни к багажу, находящемуся внутри этих транспортных средств или на этих транспортных средствах.

Перевозчик несет ответственность за ущерб, если этот ущерб причинен:

- $\quad$ в результате неисправности судна или бортовой аппаратуры;

- $\quad$ по вине лица, у которого перевозчик нанял судно, или лиц, за которых такое лицо несло бы ответственность, если бы оно само являлось перевозчиком (ст. 8).

Высадка пассажира без заявления претензий, относящихся к багажу, предполагает, если не доказано обратное, что багаж был получен им полностью и в хорошем состоянии. Претензия должна быть заявлена перевозчику либо устно, либо в письменном виде в течение семи последовательных дней с момента высадки пассажира. Пассажир освобождается от данной обязанности, если утрата или ненадлежащее состояние багажа были установлены в присутствии сторон (ст. 9). Если багаж пропал, а пассажир требует от перевозчика его выдачи, то этот багаж считается утерянным, если он не был доставлен в течение четырнадцати дней со дня заявления требования о его выдаче. Если багаж, считавшийся утерянным, найден в течение года со дня, когда пассажир потребовал его выдачи, то перевозчик должен приложить все разумные усилия для уведомления об этом пассажира. В течение тридцати дней со дня получения извещения перевозчика пассажир может потребовать доставки багажа либо в пункт отправления, либо в предусмотренный для доставки пункт. В этом случае он должен возвратить любое полученное возмещение за ущерб, связанный с утратой, при условии, однако, сохранения всех возможных прав на причитающееся в соответствии с настоящей конвенцией возмещение за повреждение или на возмещение за просрочку доставки, причитающееся в силу применяемого национального законодательства (ст. 10).

Когда возмещение ущерба за полную или частичную утрату багажа или за его повреждение возлагается на перевозчика, то может быть заявлено требование о выплате суммы, равной размеру ущерба, но эта сумма не должна превышать 5000 золотых франков на пассажира; кроме того, может быть заявлено требование о выплате суммы, равной размеру ущерба за утрату или повреждение пере- возимого транспортного средства, но эта сумма не может превышать 15000 золотых франков за транспортное средство. Данные суммы не включают понесенные сторонами для доказательства своих прав судебные издержки или другие расходы, уплата или возмещение которых могут быть возложены на перевозчика, а также проценты, исчисляемые в соответствии с законом, который сочтет применимым рассматривающий дело суд. Стороны договора перевозки могут договориться об установлении более высоких пределов ответственности перевозчика (ст. 11).

Перевозчик освобождается полностью или частично от ответственности, предусмотренной в настоящей конвенции, в той мере, в какой ущерб возник по вине пассажира или в результате такого его поведения, которое не соответствует нормальному поведению пассажира. Если перевозчик несет ответственность за ущерб, но причинению этого ущерба способствовало своими действиями или своими упущениями третье лицо, перевозчик отвечает за весь ущерб, имея право предъявить иск к этому третьему лицу. Перевозчик освобождается от ответственности, предусмотренной в настоящей конвенции, если ущерб причинен ядерным инцидентом и если в силу действующих в Договаривающемся государстве специальных предписаний, регламентирующих ответственность в области ядерной энергии, ответственность за этот ущерб возлагается на оператора ядерной установки или на другое заменяющее его лицо (ст. 12).

Во всех случаях, регламентируемых настоящей конвенцией, любой иск в отношении ответственности, каким бы ни было его основание, может быть предъявлен к перевозчику или лицам, за действия которых он несет ответственность, только на условиях и в пределах, предусмотренных в настоящей конвенции. Перевозчик не вправе ссылаться на положения настоящей конвенции, исключающие полностью или частично его ответственность или ограничивающие подлежащее уплате возмещение, если ущерб причинен в результате умысла или грубой небрежности перевозчика или лиц, за действия которых он несет ответственность. Общий размер возмещения, причитающегося с перевозчика и лиц, за действия которых перевозчик несет ответственность, не может превышать сумм, предусмотренных в настоящей конвенции (ст. 13).

2) Порядок разрешения споров, связанных с неисполнением или ненадлежащим исполнением договора перевозки пассажиров и багажа

По всем спорам, возникающим по поводу перевозок, подпадающих под действие Женевской конвенции, 
DOI: $10.7256 / 1811-9018.2013 .10 .9193$

При цитировании этой статьи сноска на dоі обязательна

\section{Право и политика 10 (166) • 2013}

истец может по своему выбору обратиться, помимо компетентных судов Договаривающихся государств, определенных сторонами с общего согласия, к судам государства, на территории которого находится:

- главная контора ответчика, его обычное местожительство или контора, при посредстве которой был заключен договор перевозки; или

- $\quad$ место, где был причинен ущерб; или

- $\quad$ место отправления или назначения (при этом истец может обратиться лишь к этим судам).

Когда при возникновении какого-либо спора дело находится в производстве суда, компетентного в силу вышеуказанного положения, или когда по такому спору этим судом было вынесено решение, не должно быть возбуждено новое дело между теми же сторонами и на том же основании, за исключением случаев, когда решение суда, в котором был предъявлен первый иск, не подлежит исполнению в государстве, в котором предъявлен новый иск. Когда по какому-либо спору решение, вынесенное компетентным судом одного из Договаривающихся государств, подлежит исполнению в этом государстве, данное решение становится подлежащим исполнению также в каждом из других Договаривающихся государств по выполнении предусмотренных для этого формальностей в этом государстве. Пересмотр дела по существу не производится.

Данные положения относятся к решениям, вынесенным в присутствии сторон, к заочным решениям и к примирительному судопроизводству, но не относятся ни к судебным решениям, подлежащим исполнению в предварительном порядке, ни к решениям, согласно которым истец, в случае полного или частичного отказа в иске, должен не только оплатить судебные издержки, но и возместить убытки, понесенные ответчиком. Суд не вправе требовать от граждан Договаривающихся государств, местожительство или контора которых находится в одном из таких государств, внесения залога для обеспечения уплаты судебных издержек, связанных с предъявлением иска, касающегося перевозок, которые подпадают под действие настоящей конвенции (ст. 15).

Право на предъявление иска в связи со смертью, телесными повреждениями или нанесением любого другого ущерба физическому или психическому здоровью пассажира, погашается по истечении трех лет. Срок давности исчисляется со дня, когда лицо, которому был причинен ущерб, узнало об этом. Однако срок давности не может превышать пяти лет, считая со дня происшествия. Право на предъявление иска в отношении перевозки, подпадающей под действие настоящей конвенции, кроме вышеупомянутой категории исков, погашается во всех случаях по истечении одного года. Срок давности исчисляется со дня прибытия судна в пункт назначения пассажира или, в случае неприбытия, со дня, когда оно должно было прибыть туда. Заявление претензии в письменном виде приостанавливает течение давности до того дня, когда перевозчик в письменном виде отклоняет претензию и возвращает приложенные к ней документы, которые были вручены ему в ее обоснование. В случае частичного признания заявленной претензии течение давности возобновляется только в отношении той части претензии, которая остается предметом спора. Бремя доказывания факта получения претензии или ответа на нее, а также возвращения относящихся к делу документов лежит на стороне, которая ссылается на этот факт. Заявление дальнейших претензий по тому же вопросу не приостанавливает течения давности, если перевозчик не соглашается их рассматривать. Условия приостановления течения срока давности определяются законом суда, в котором предъявлен иск, за исключением его коллизионных норм. Этим же законом определяются условия прерывания срока давности (ст. 17).

Признается не имеющим силы любое условие договора, которым прямо или косвенно допускается отступление от положений настоящей конвенции. Недействительность такого условия не влечет за собой недействительности других условий договора. В частности, недействительным является любое условие, согласно которому перевозчику уступаются права, вытекающие из какого-либо договора страхования, заключенного в пользу пассажира, или любое другое аналогичное условие, а также любое положение, перекладывающее бремя доказывания. Недействительным является также любое условие, наделяющее компетенцией арбитражный суд, оговоренное до события, явившегося причиной возникновения ущерба $(\text { ст. } 18)^{20}$. В данной научной работе использованы результаты, полученные в ходе выполнения проекта

\footnotetext{
${ }^{20}$ В последнем случае речь идет об арбитражной оговорке. Таким образом, Женевская конвенция предусматривает довольно любопытное регулирование порядка рассмотрения споров из международной речной перевозки пассажиров и багажа. Конвенция прямо запрещает арбитражные оговорки, однако, по смыслу ст. 18 , допускает заключение арбитражного соглашения в форме арбитражного компромисса, носящего ретроспективный характер и формируемого сторонами спора после его возникновения.
} 
DOI: $10.7256 / 1811-9018.2013 .10 .9193$

При цитировании этой статьи сноска на doi обязательна

Международное право в XXI веке

«Кодификационные и унификационные процессы в международном частном праве», выполненного в рамках Программы «Научный фонд НИУ ВШЭ» в 2013 году, грант № 12-05-0020. Настоящая статья подготовлена при поддержке Правовой информационно-справочной системы «Консультант Плюс».

\section{Библиография:}

1. Асосков А.В. Коллизионное регулирование договорных обязательств. М., 2012.

2. Вознесенская Н.Н. Международное частное право и сравнительное правоведение // Вестник Государственной регистрационной палаты при Министерстве юстиции РФ. 2012. № 6.

3. Гречуха В.Н. Международное транспортное право: Учебник. М., 2013.

4. Касаткина А.С. Правовое понятие и классификация международных пассажирских перевозок // Адвокат. 2011. № 3.

5. Касаткина А.С. Коллизионное и материальное регулирование международных пассажирских перевозок // Международное право и международные организации. 2012. № 4.

6. Касаткина А.С. Правовые основы регулирования международных пассажирских перевозок // Право и политика. 2012. № 3.

7. Кокин А.С. Международная морская перевозка груза: право и практика. М., 2012.

8. Кокин А.С., Левиков Г.А. Транспортно-экспедиторские услуги при международной перевозке грузов. М., 2011.

9. Ротко С.В. Коносамент в российском и зарубежном законодательстве // Международное публичное и частное право. 2011. № 1.

10. Степин А.Б. Критерии и условия реализации международных средств защиты частного права // Современное право. 2011. № 12.

11. Степин А.Б. Понятие и сущность международных стандартов защиты частного права // Международное публичное и частное право. 2012. № 1.
12. Холопов К.В. Международное частное транспортное право: Анализ норм международного и российского транспортного права. М., 2010.

\section{References (transliteration):}

1. Asoskov A.V. Kollizionnoe regulirovanie dogovornykh obyazatel'stv. M., 2012.

2. Voznesenskaya N.N. Mezhdunarodnoe chastnoe pravo i sravnitel'noe pravovedenie // Vestnik Gosudarstvennoi registratsionnoi palaty pri Ministerstve yustitsii RF. 2012. № 6.

3. Grechukha V.N. Mezhdunarodnoe transportnoe pravo: Uchebnik. M., 2013.

4. Kasatkina A.S. Pravovoe ponyatie i klassifikatsiya mezhdunarodnykh passazhirskikh perevozok // Advokat. 2011. № 3 .

5. Kasatkina A.S. Kollizionnoe i material'noe regulirovanie mezhdunarodnykh passazhirskikh perevozok // Mezhdunarodnoe pravo i mezhdunarodnye organizatsii. 2012. № 4.

6. Kasatkina A.S. Pravovye osnovy regulirovaniya mezhdunarodnykh passazhirskikh perevozok // Pravo i politika. 2012. № 3 .

7. Kokin A.S. Mezhdunarodnaya morskaya perevozka gruza: pravo i praktika. M., 2012.

8. Kokin A.S., Levikov G.A. Transportno-ekspeditorskie uslugi pri mezhdunarodnoi perevozke gruzov. M., 2011.

9. Rotko S.V. Konosament v rossiiskom i zarubezhnom zakonodatel'stve // Mezhdunarodnoe publichnoe i chastnoe pravo. 2011. № 1 .

10. Stepin A.B. Kriterii i usloviya realizatsii mezhdunarodnykh sredstv zashchity chastnogo prava // Sovremennoe pravo. 2011. № 12.

11. Stepin A.B. Ponyatie i sushchnost' mezhdunarodnykh standartov zashchity chastnogo prava // Mezhdunarodnoe publichnoe i chastnoe pravo. 2012. № 1 .

12. Kholopov K.V. Mezhdunarodnoe chastnoe transportnoe pravo: Analiz norm mezhdunarodnogo i rossiiskogo transportnogo prava. M., 2010. 